\title{
White piedra and pediculosis capitis in the same patient *
}

\author{
Piedra branca e pediculose capitis no mesmo paciente
}

\author{
Silvio Alencar Marques ${ }^{1}$ \\ Rosângela Maria Pires de Camargo ${ }^{3}$
}

\author{
Virgínia Bodelão Richini-Pereira
}

\begin{abstract}
White piedra is a superficial mycosis caused by the genus Trichosporon. It is characterized by nodules on the hair shaft. Pediculosis capitis is caused by Pediculus humanus var. capitis of the suborder Anoplura. Whereas pediculosis is a common infestation, clinical reports of white piedra are rare. Molecular biology procedures identified $\mathrm{T}$. inkin as the agent of white piedra in this case report. The authors present associations between the two diseases in the same patient in order to highlight their clinical differences.

Keywords: Lice infestations; Piedra; Trichosporon

Resumo: Piedra branca é micose superficial causada pelo gênero Trichosporon e caracterizada por nódulos aderidos à haste do pelo. Pediculose capitis é causada pelo Pediculus humanus var. capitis pertencente à subordem Anoplura. Enquanto que a pediculose é enfermidade comum, relatos clínicos de piedra branca são raros. Técnicas de biologia molecular identificaram o agente de piedra branca do presente relato como T.inkin. Os autores apresentam associação de ambas as infestações no mesmo paciente para salientar seus aspectos clínicos distintos.

Palavras-chave: Infestações por piolhos; Piedra; Trichosporon
\end{abstract}

White piedra is characterized by whitish nodules firmly attached to the hair shaft. It occurs in tropical and subtropical regions, and humidity associated with poor personal hygiene is a predisposing factor. ${ }^{1.3}$ Pediculosis capitis is a worldwide infestation, and it is related to close personal contact or comb and hairbrush sharing. The association of both diseases in the same patient is uncommon, and it may be overlooked due to inattentive or careless examination. We report the case of a 21-year-old woman who complained of whitish spots on scalp hair shafts and of mild local pruritus. On examination, whitish nodules firmly attached to hair shafts and similar, not firmly attached nodules were observed on the same or on isolated hair shafts (Figure 1). Dermoscopy and direct examination identified distinct infectious agents (Figures 2

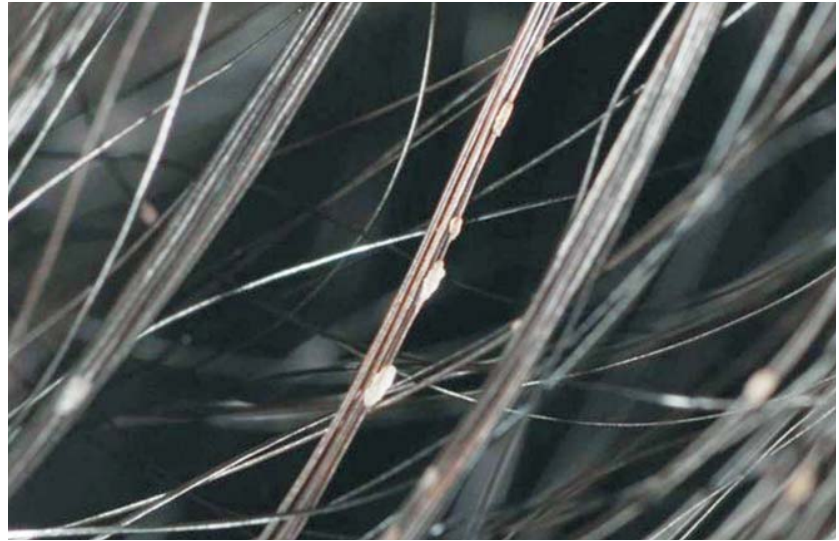

Figure 1: Nodules of white piedra on the upper part of the hair and lice of pediculosis on the lower part of the hair and 3). Trichosporon spp. was cultured on Sabouraud-

Received on 10.03.2012.

Approved by the Advisory Board and accepted for publication on 23.04.2012.

* Work conducted at the Department of Dermatology and Radiotherapy, Faculdade de Medicina de Botucatu (School of Medicine of Botucatu), Universidade Estadual Paulista "Julio de Mesquita Filho" (Julio de Mesquita Filho Sao Paulo State University - (FMB-UNESP) - Botucatu (SP), Brazil. Conflict of interest: None

Financial funding: None

Full professor - Professor, Department of Dermatology and Radiotherapy, Faculdade de Medicina de Botucatu (School of Medicine of Botucatu), Universidade Estadual Paulista "Julio de Mesquita Filho" (Julio de Mesquita Filho Sao Paulo State University - (FMB-UNESP) - Botucatu (SP), Brazil.

Post-doctoral student - Department of Veterinary Hygiene and Public Health, Universidade Estadual Paulista "Júlio de Mesquita Filho" (UNESP) - Botucatu (SP), Brazil.

Biologist - Laboratory of Medical Mycology, Department of Dermatology and Radiotherapy, Faculdade de Medicina de Botucatu, Universidade Estadual Paulista "Julio de Mesquita Filho" - (FMB-UNESP) - Botucatu (SP), Brazil. 


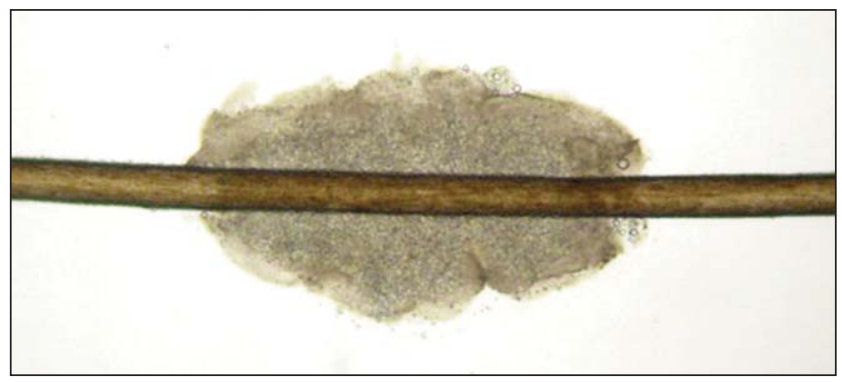

FIGURE 2: Direct microscopic examination of a nodule of white piedra with arthroconidia attached to the hair

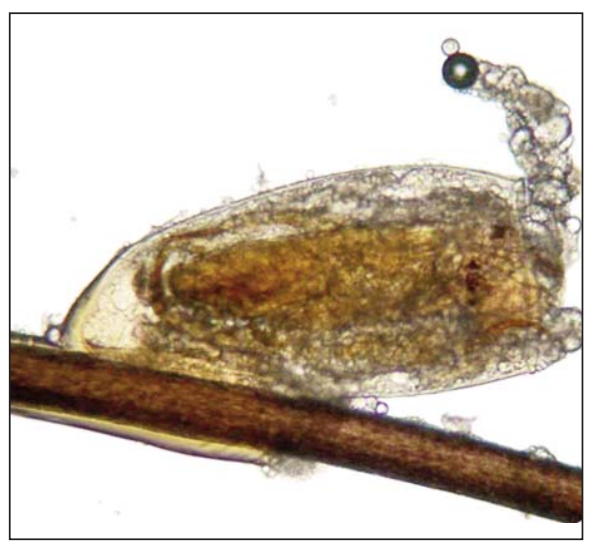

Figure 3: Direct microscopic examination showing viable louse attached to the hair
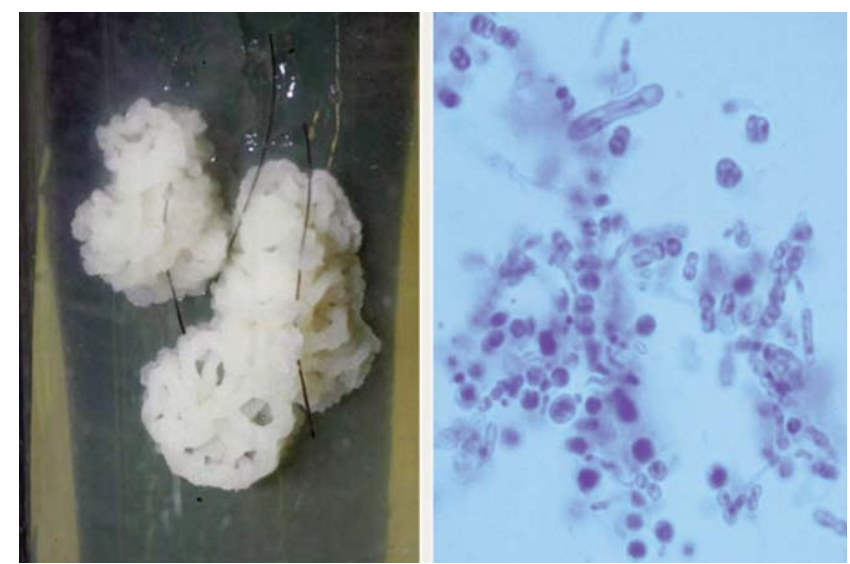

FIGURE 4: Yeast culture with a cerebriform aspect and microculture showing the presence of arthroconidia of different shapes and blastoconidia; diagnoses of Trichosporon spp

dextrose agar. Then, it was identified by molecular methods using ITS 4 and ITS 5 primers, compared with information on the NCBI database and finally confirmed as Trichosporon inkin (access: HM046988.1 GI:295824566) (Figure 4). ${ }^{4,5}$ White Piedra was treated with ketoconazole shampoo, and pediculosis was treated with ivermectin, with successful results, which remained over a one-year follow-up period.

\section{REFERENCES}

1. Chagas-Neto TC, Chaves GM, Colombo AL. Update on the Genus Trichosporon. Mycopathologia. 2008;166:121-32.

2. Diniz LM, Souza Filho JB. Estudo de 15 casos de piedra branca observados na Grande Vitória (Espirito Santo-Brasil) durante cinco anos. An Bras Dermatol. 2005;80:49-52.

3. Roselino AM, Seixas AB, Thomazini JA, Maffei CML. An outbreak of scalp white piedra in a Brazilian day care. Rev Inst Med Trop São Paulo. 2008;50:307-9.

4. Sugita T, Nakajima M, Ikeda R, Mattsushima T, shinoda T. Sequences analysis of the ribossomal DNA intergenic spaces 1 region of Trichosporon species. J Clin Microbiol. 2002;40:1826-30

5. Pincus DH, Orenga S, Chatellier S. Yeast identification-past, present, and future methods. Med Mycol. 2007:45:97-121.

\author{
MAILING ADDRESS / ENDEREÇO PARA CORRESPONDÊNCIA: \\ Silvio Alencar Marques \\ Depto. de Dermatologia e Radioterapia \\ Faculdade de Medicina - UNESP-Botucatu \\ Distrito de Rubião Júnior, $s / n-$ \\ 18618-970 Botucatu, SP \\ E-mail address: smarques@fmb.unesp.br
}

How to cite this article: Marques AS, Richini-Pereira VB, Camargo RMP. White piedra and pediculosis capitis in the same patient. An Bras Dermatol. 2012;87(5):786-7. 